\title{
Screening of Supports for Immobilization of Commercial Porcine Pancreatic Lipase
}

\author{
Robison Scherer ${ }^{\mathrm{a}}$,José Vladimir Oliveira ${ }^{\mathrm{a}}$, Sibele Pergher ${ }^{\mathrm{b}}$, Débora de Oliveira* ${ }^{\text {a* }}$ \\ ${ }^{a}$ Departamento de Engenharia de Alimentos, \\ Universidade Regional Integrada do Alto Uruguai e das Missões - URI, \\ Campus de Erechim, Av. 7 de Setembro, 1621, CEP 99700-000, Erechim, RS, Brazil \\ ${ }^{\mathrm{b}}$ Centro de Ciências Exatas, Departamento de Química, \\ Universidade Federal do Rio Grande do Norte - UFRN, \\ Av. Salgado Filho, 3000, Lagoa Nova, CEP 59078-970, Natal, RN, Brazil
}

Received: February 16, 2011; Revised: August 10, 2011

\begin{abstract}
The aim of this work is to report the performance of different supports for the immobilization of commercial porcine pancreatic lipase. The immobilization tests were carried out in several types of Accurel, activated alumina, kaolin, montmorillonite, ion exchange resins and zeolites. The characterization of the supports showed differences in terms of specific area and morphology. The characteristics of the supports influenced the amount of enzyme adsorbed, yield of immobilization and esterification activity of the resulting immobilized catalyst. The clays KSF and natural and pillared montmorillonites presented potential for use as support for lipase immobilization in terms of yield and esterification activity. Yields of immobilization of 76.32 and $52.01 \%$ were achieved for clays KSF and natural montmorillonite, respectively. Esterification activities of 754.03, 595.51, 591.88 and 515.71 U.g ${ }^{-1}$ were obtained for lipases immobilized in Accurel MP-100, Amberlite XAD-2, mordenite and pillared montmorillonite, respectively.
\end{abstract}

Keywords: porcine pancreatic lipase, immobilization, screening, supports

\section{Introduction}

Lipases catalyzing lipid modifications have attracted considerable attention over the last years. The attractive aspects of this catalyst over chemical methods include the high specificity of some lipases, the mild conditions required for reactions to take place, thereby requiring minimal energy inputs, reduced levels of by-products generated during the reaction and more efficient conversion of thermo sensitive substrates $^{1-3}$. These catalysts play an important role in biotechnology, not only in food and oil processing but also in the preparation of chiral intermediates. In fact, about $30 \%$ of all biotransformation reactions reported up to today have been performed with lipases.

Besides the potential of lipases as biocatalysts for reactions of interest, the high cost for application in industrial processes is related to their reduced stability under adverse conditions. The enzyme stabilization is a desirable process from an economical point of view ${ }^{4-6}$. The immobilization of biocatalysts in innert supports (without damage to the enzyme activity) can ensure their use for several batches, resulting in economy for industrial processes ${ }^{7}$. The main advantages of immobilized enzymes are related to their higher stability and easy separation from the reaction medium ${ }^{8}$.

The highest contribution for the good performance of immobilized catalyst is provided by the strategy employed for immobilization ${ }^{9}$ and by the characteristics of the support. The screening of the most appropriate support can enhance the half-time of the enzyme and also the global performance of the process ${ }^{10}$. The immobilization of lipases is still a complex challenge, since the efficiency of the process depends on the structure of the enzyme, the method of immobilization and the type of support ${ }^{11}$. Some studies show that several organic, inorganic and natural materials with different characteristics have been used for lipases immobilization ${ }^{4,6,7}$. Several works pointed out the use of porous inorganic supports of high cost due to their properties of mechanical resistance and specific surface area ${ }^{10,12}$. The use of low cost supports presenting high activated internal surface and hydrophobic characteristics can be recognized by lipases in molecular level as solid interfaces. The use of hydrophobic supports is preferable for lipases immobilization as they present low tendency of competing by the available water in the reaction system ${ }^{4}$.

In this sense, immobilization of lipases has been accomplished either by physical adsorption method or by chemical linkage using synthetic polymers or natural polymeric derivatives ${ }^{13-15}$ as well as inorganic materials ${ }^{6,16}$.

Based on the above mentioned aspects and the fact that no systematic work was found in the open literature about the immobilization of porcine pancreatic lipase, the aim of this work was to perform the screening of suitable supports for immobilization of this commercial lipase. The screening step was preceded by partial characterization studies that afforded fundamental information on the solid and surface properties of each support. The enzyme immobilization was carried out, determining the amount of protein adsorbed, the yield of immobilization and the esterification activity for the twenty one supports used.

\section{Experimental}

\subsection{Enzyme}

Lipase (EC 3.1.1.3 Type II, crude; from porcine pancreas) was purchased from Sigma-Aldrich and used for immobilization in different supports. The enzyme is a liophylized powder, color 
yellow, optima values of $\mathrm{pH}$ from 6.5 to 7.5 and moderately soluble in organic solvents.

\subsection{Supports for immobilization}

The supports used for the immobilization of porcine pancreatic lipase were: Accurel MP-100 (Nortec); Accurel MP-1000 (Nortec); Accurel XP-100 (Nortec); Accurel XP-200 (Nortec); acid activated alumina (Merck); base activated alumina (Merck); neutral activated alumina (Merck); Kaolin (Reagen); Kaolin 1CR (Mineração Tabatinga - PR); natural montmorillonite (Colorminas Colorificio e Mineração S/A); montmorillonite K-10 (Sigma-Aldrich); montmorillonite KSF (Sigma-Aldrich); pillared montomorillonite; resin Amberlyst 36 (wet) (Sigma-Aldrich); resin Amberlite XAD-2 (Sigma-Aldrich); zeolite mordenite; zeolite Y; zeolite ZSM-22; zeolite NaX and zeolite ZSM-35;

\subsection{Characterization of the supports}

The supports were partially characterized in terms of specific area and X-ray difraction. The textural characterization of the supports was carried out using an Autosorb-1 (Quantachrome Nova-2200e). Before analysis, about $100 \mathrm{mg}$ of each support was treated under vacuum, at $300{ }^{\circ} \mathrm{C}$ for 3 hours. Measurements were performed at the temperature of liquid $\mathrm{N}_{2}$. Average specific area was determined by the BET method. The X-ray analyses of the supports were carried out in a Diffraktometer model D5000 (Siemens) using filter of $\mathrm{Ni}$ and radiation $\mathrm{Cu}-\mathrm{k} \alpha(\lambda=1.54 \AA)$.

\subsection{Experimental procedure for lipase immobilization}

The lyophilized preparation was solubilized in phosphate buffer (0.05 mol.L $\left.\mathrm{L}^{-1}, \mathrm{pH} 7.0\right)$ ( $2 \mathrm{~g}$ of commercial enzymatic extract and $60 \mathrm{~mL}$ of buffer) and submitted to preferential immobilization by physical adsorption on each support presented before. Enzyme immobilization was performed at a mass ratio enzyme to support of $2: 1$. Immobilization was carried out with magnetic stirring in an ice cooler and aliquots were sampled periodically until 120 minutes for protein content assay. The supernatant and carrier with enzyme were also assayed for measurement of esterification activity, following the methodology described in the next section.

\subsection{Analytical methodology}

\subsubsection{Protein content}

The protein content in the inlet and outled solutions was measured by the methodology proposed by Bradford ${ }^{17}$, using serum bovine albumine as standard. Samples were analyzed in spectrophotometer (Agilent Tecnologies 8453) at $595 \mathrm{~nm}$ and the protein content was determined by Equation 1.

$$
\text { protein }=\frac{A b s .}{f} \cdot 10 . d
$$

where protein means the protein content $\left(\mathrm{mg} \cdot \mathrm{mL}^{-1}\right)$, Abs is the absorbance at $595 \mathrm{~nm}, \mathrm{~d}$ denotes the dilution of the samples and $\mathrm{f}$ is the factor obtained in the calibration curve.

The yield of immobilization was calculated by Equation 2,

$$
\eta(\%)=\frac{P a}{P o} \times 100
$$

where $=$ yield $(\%)$, Pa represents the amount of protein adsorbed, Po denotes the amount of protein used in the immobilization (inlet solution).

\subsubsection{Lipase esterification activity}

The enzyme activity was determined as the initial rates in esterification reactions between oleic acid and ethanol at a molar ratio of 1:1 using $0.4 \mathrm{~g}$ of enzyme (immobilized in each support tested or in its free form). At the beginning of the reaction, samples containing the mixture of oleic acid and ethanol were collected, and the oleic acid content was determined by titration with 0.04 mol. $\mathrm{L}^{-1}$ $\mathrm{NaOH}$. After the addition of the enzyme to the substrates, the mixture was kept at $40{ }^{\circ} \mathrm{C}$ and $150 \mathrm{rpm}$ for 40 minutes. Then, the oleic acid consumption was determined ${ }^{18}$. One lipase activity unit (UE) was defined as the amount of enzyme necessary to consume $1 \mu \mathrm{mol}$ of oleic acid per minute at the established experimental conditions presented previously. All enzymatic activity determinations were replicated at least three times. Results presented here are in fact mean values of the measurements performed. Standard errors low than 5\% were obtained in all determinations (data not shown).

\section{Results and Discussion}

\subsection{Characterization of the supports}

The class of supports evaluated here were: clays, zeolites, ion exchange resins, oxides and polymeric resins. The specific areas and $\mathrm{X}$-ray diffraction were determined for each support used for lipase immobilization.

\subsection{Specific areas}

Table 1(a) presents the specific areas of the clays materials used in this work. These materials have lamellar structure, that if is ordenaded gives specific areas of $4-61 \mathrm{~m}^{2} \cdot \mathrm{g}^{-1}$. The $\mathrm{K}-10$ clay has high specific area because of acid treatment that delaminated and destroyed partially the lamellar structure. One can also verify the efficiency of the process of pillarization, since the area of the natural montmorillonite was significantly increased (about 3 times) compared to the pillared one. Table 1(b) presents the specific area of zeolites Y, ZSM-22, ZSM-35, ZSM-5, NaX, and mordenite. Zeolite $\mathrm{Y}$ presented the highest specific area from all evaluated zeolites probably because its higher pore size. Table 1(c) shows that Amberlite XAD-2 presents a specific area about 6 times higher than Amberlyst 36 (wet). Table 1(d) presents the specific area for the aluminas which are similar, independent of acidity or basicidity.. From Table 1(e) one can observe that the different Accurel supports tested here presented specific area lower than all other evaluated supports.

Results regarding structural characterization of the solid catalysts presented in Table 1 showed that several materials can be considered microporous, since pore diameters (data not shown) smaller that $20 \AA$ were obtained. All other tested supports are characterized as mesoporous (pore diameter in the range of 20 to $50 \AA$ ). The greatest value of specific specific area was observed for zeolites $\mathrm{Y}$ and $\mathrm{NaX}$.

One should notice that some of the supports tested presented small average pore diameter (data not shown), which may be the reason for the low yield of immobilization, as will be presented later. Of course, small pore diameters may hinder or even avoid the access of enzyme to the internal structure of the support, making difficult the diffusion, thus limiting mass transfer process and accordingly reducing the yield of immobilization. In fact, it is interesting to note that though the zeolites exhibit high specific area, they possess, comparatively, one of the smallest pore diameters and as a consequence they afforded one of the worst results in terms of yield of immobilization. Thus, this structural parameter may be of relevance in the present context considering the chain length and molar mass of the material (enzyme) in use. 
Table 1. Specific areas of supports employed for immobilization of porcine pancreatic lipase.

\begin{tabular}{lc}
\multicolumn{2}{c}{ a) Clays } \\
\hline \multicolumn{1}{c}{ Support } & Area $\left(\mathrm{m}^{2} \cdot \mathrm{g}^{-1}\right)$ \\
\hline Montmorillonite K-10 & 224 \\
Montmorillonite KSF & 12 \\
Kaolin commercial & 4 \\
Kaolin Mina 1CR & 61 \\
Pillared montmorillonite & 227 \\
Natural montmorillonite & 58 \\
\hline \multicolumn{1}{c}{ Support } & b) Zeolites \\
\hline Zeolite Y & Area $\left(\mathrm{m}^{2} \cdot \mathrm{g}^{-1}\right)$ \\
Zeolite ZSM 22 & 568 \\
Zeolite ZSM 35 & 39 \\
Zeolite ZSM 5 & 277 \\
Zeolite NaX & 365 \\
Mordenite & 432 \\
\hline
\end{tabular}

\begin{tabular}{|c|c|}
\hline \multicolumn{2}{|c|}{ c) Ion exchange resins } \\
\hline Support & Area $\left(\mathrm{m}^{2} \cdot \mathrm{g}^{-1}\right)$ \\
\hline Resin Amberlyst 36 (wet) & 43 \\
\hline Resin Amberlite XAD-2 & 277 \\
\hline \multicolumn{2}{|c|}{ d) Aluminas } \\
\hline Support & Area $\left(\mathrm{m}^{2} \cdot \mathrm{g}^{-1}\right)$ \\
\hline Acid alumina & 152 \\
\hline Basic alumina & 141 \\
\hline Neutral alumina & 127 \\
\hline \multicolumn{2}{|c|}{ e) Polymeric resins } \\
\hline Support & Area $\left(\mathrm{m}^{2} \cdot \mathrm{g}^{-1}\right)$ \\
\hline Accurel XP-100 & - \\
\hline Accurel MP-100 & 9 \\
\hline Accurel XP-200 & - \\
\hline Accurel MP-1000 & 38 \\
\hline
\end{tabular}

\subsection{X-ray diffraction}

Figure 1a presents the X-ray diffractograms of zeolite materials that confirm the structure of these materials when compared to standards diffractograms (IZA).

Figure $1 \mathrm{~b}$ presents the X-ray diffractograms of the supports used for lipase immobilization. The X-ray diffractogram of K-10 clay presents large reflection at $2 \theta=6^{\circ}(\mathrm{d}=14.7 \AA)$, indicating an argilomineral of group of esmectite. Reflections at $2 \theta=9^{\circ}$ $(\mathrm{d}=10.0 \AA)$ and $2 \theta=18^{\circ}(\mathrm{d}=4.9 \AA)$ are also observed, suggesting the presence of mica. The KSF clay presented reflection at $2 \theta=6^{\circ}$ ( $d=14.7 \AA$ ), equivalent to the group of esmectite. Both clays presented strong reflection at $2 \theta=27.4^{\circ}(\mathrm{d}=3.25 \AA)$, indicating the presence of quartz. The diffractograms of the supports KSF and $\mathrm{K}-10$ have reflections related to the esmectite group; low evidenced compared to the natural clays.

Figure $1 \mathrm{~b}$ also shows the diffractograms for commercial and 1CR Kaolins. Both materials could be classified as caulinites. The natural Kaolin presents some impurities as mica, gibsite and quartz. Commercial Kaolin demonstrates high cristallinity presenting low amount of caulinite.
The diffractograms of natural and pillared montmorillonites showed that the natural clay presents the first peak $\left(\mathrm{d}_{001}\right)$ related to the basal spacing, corresponding to $15.12 \AA$. The peak observed at $2 \theta=20^{\circ}$ is characteristic of motmorillonite clays. The peak between $25^{\circ}$ and $30^{\circ}$ corresponds to the quartz. For pillared montmorillonite, the calculated value by Bragg Law for the distance $\mathrm{d}_{001}$ corresponded to $18.62 \AA$. The basal distance for natural clays is $15 \AA$, but when water is present, the basal distance can be increased, as in this case. When the clay is calcinated, the dehydratation process occurs and the basal spacing decreases for approximately $9 \AA$. In the pillarization process, the basal spacing increases 2 times its value (from 9.0 to $18.6 \AA$ ). Comparing the diffractograms of natural and pillared clays, one can note that the peak corresponding to the basal spacing $\left(\mathrm{d}_{001}\right)$ displaces to the left, indicating the occurrence of the pillarization of the material.

Alumina materials showed a typical diffratogram for this class of amorphous materials (Figure 1c). The resins are amorphous too, as showed in Figure 1d. Accurel materials have similar diffractogram patterns with an exception of XP-200.(Figura 1e)

\subsection{Immobilization of lipases in different supports}

\subsubsection{Clays}

Figure 2a presents the kinetics of commercial lipase adsorption in clays, where one can see that in all supports the adsorption process of the enzyme occurred. Some works presented in the literature have already shown the use of clays as support for enzymes immobilization ${ }^{19-24}$.

Table 2 (a) presents the results in terms of adsorbed protein, yield of immobilization, amount of lipase immobilized and esterification activity for the free and immobilized enzymes using several clays as support. The immobilization process was more efficient for clays KSF, natural and pillared montmorillonites with yields of immobilization of about $50 \%$ (based on the amount of free enzyme used at the beginning of the process). This fact can be related to the higher chemical affinities of the enzyme by these supports, as already demonstrated by some works of the literature. The works by Li et al..$^{25-26}$ showed that the free hydroxil groups present in the surface of these supports can form hydrogen bounds with the functional groups of aminoacids chains of the enzyme, promoting higher efficiency to the immobilization process. The van der Waals forces can also help the adsorption of the enzyme to the surface of the support. Additionally, the hydrophobic interactions of enzyme-support molecules can contribute to the adsorption process ${ }^{27}$.

The Kaolins have a neutral 1:1 structure while the montmorillonites have a 2:1 structure and high capacity of cationic exchange (CCE), favoring the immobilization in this kind of support. Rahman et al. ${ }^{21}$ immobilized the Candida rugosa lipase by adsorption method using natural Kaolin as support. Retention of about $77 \%$ was achieved.

Other authors have also used different clays as support for enzymes immobilization. Zamora et al. ${ }^{28}$ immobilized lacase from Trametes versicolor in montmorillonite KSF natural and modified by 3-amino-propyl-triet-xisilane and glutarahaldeyde. The authors reached yields of immobilization of 16 and 55\%, respectively. Gopinath and Sugunan ${ }^{23}$ and Sanjay and Sugunan ${ }^{22}$ immobilized $\alpha$-amylase, glucoamylase and invertase in montmorillonite K-10 by adsorption and covalent bound techniques. High yields of immobilization were obtained by analysis of nitrogen adsorption isoterms (BET). The authors observed a reduction in the specific area from 201 to 45,15 and $10 \mathrm{~m}^{2} . \mathrm{g}^{-1}$ after the immobilization process for each enzyme, respectively. Results corroborate the affirmation that different enzymes can present different behavior in the same support. 


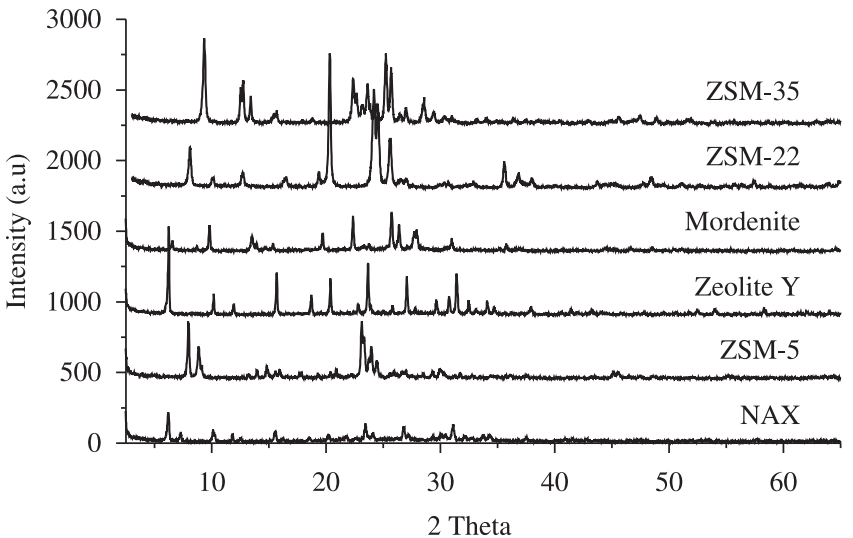

(a)

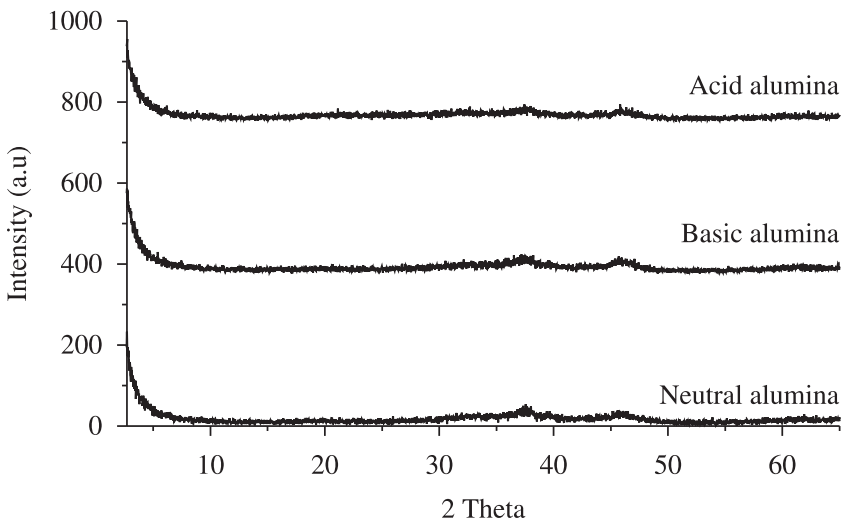

(c)

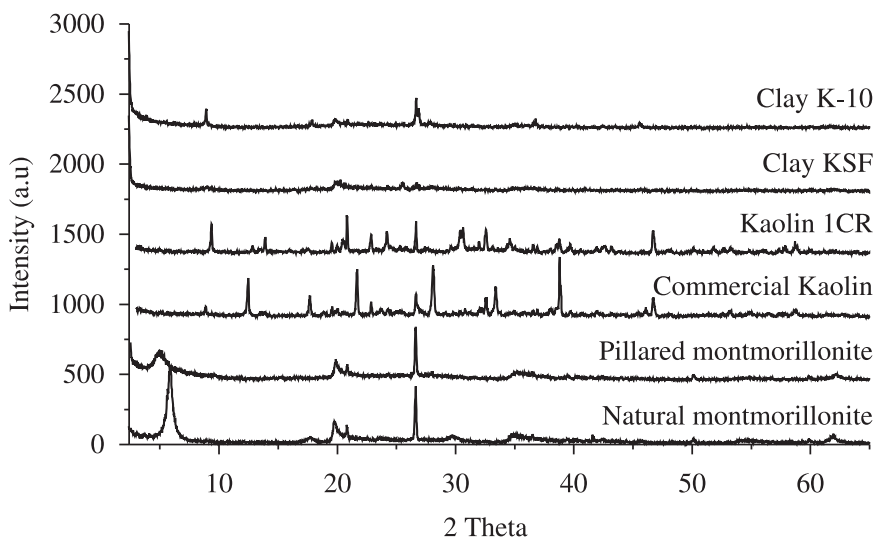

(b)

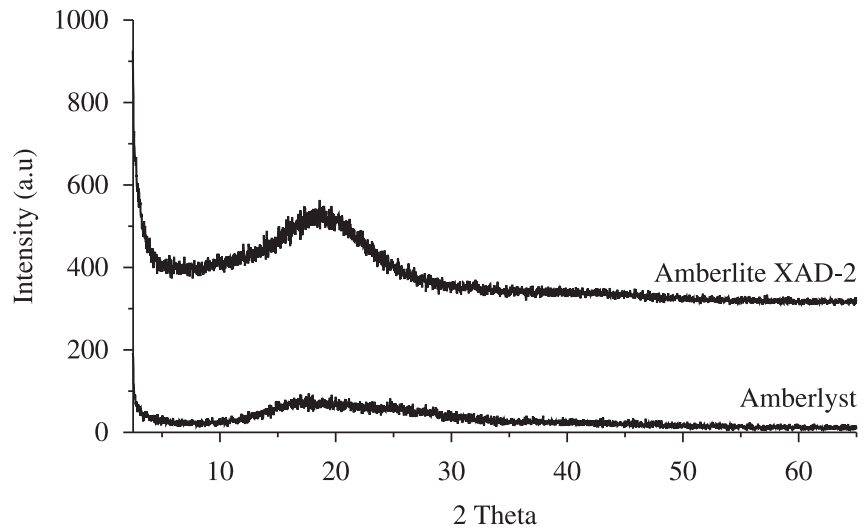

(d)

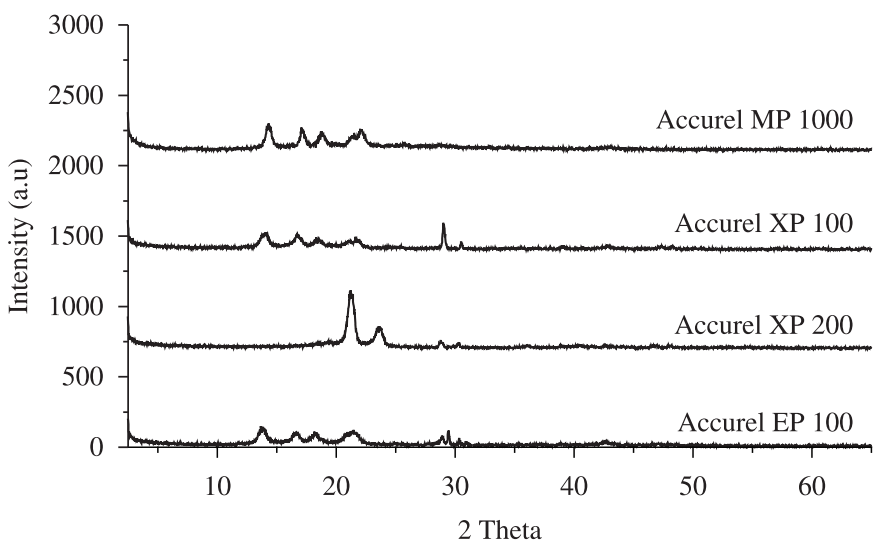

(e)

Figure 1. X-Ray diffractogram of supports: a) zeolites; b) Clays; c) aluminas; d) resins; and e) Accurel.

Yesiloglu $\mathrm{u}^{20}$ used bentonite for immobilization of Candida rugosa lipase by adsorption process, presenting enzymatic activity of $30 \%$ after immobilization. Spagna et al. ${ }^{29}$ immobilized a commercial pectinilyase in bentonite achieving a yield of immobilization of $16 \%$ and enzyme activity of $67 \mathrm{U} . \mathrm{g}^{-1}$. Chang et al. ${ }^{30}$ immobilized Candida rugosa lipase on Celite and obtained residual activities after immobilization of $34.1 \%$. Zaidan et al. ${ }^{31}$ used mica modified by acid treatment as support for the immobilization of Candida rugosa lipase, reaching a yield higher than $78 \%$ and specific enzyme activity of $83 \mathrm{U} . \mathrm{mg}^{-1}$ of protein. Meunier et al. ${ }^{24}$ tested different types of Celite as support for immobilization of a commercial lipase (Novozym 435) and obtained yields of about $60 \%$. Secundo et al. ${ }^{32}$ immobilized
Candida antarctica lipase in clays beidelite with different ratios of $\mathrm{Si} / \mathrm{Al}$. The yields of immobilization were 24 and $35 \%$ in $\mathrm{pH}$ values of 6 and 7, respectively.

The interlammelar region of pillared montmorillonite is constituted by pillars, which reduce the capacity of cationic exchange. This factor can explain the lowest yields of immobilization obtained in this support, in spite of the higher acessibility of the enzyme to the support.

The literature presents just a few works related to the esterification activities of lipases immobilized in clays. Dave et al. ${ }^{33}$ immobilized Candida rugosa lipase in a polymer of polyvinilic alcohol (PVA), calcium alginate and boric acid. The immobilized lipase presented 

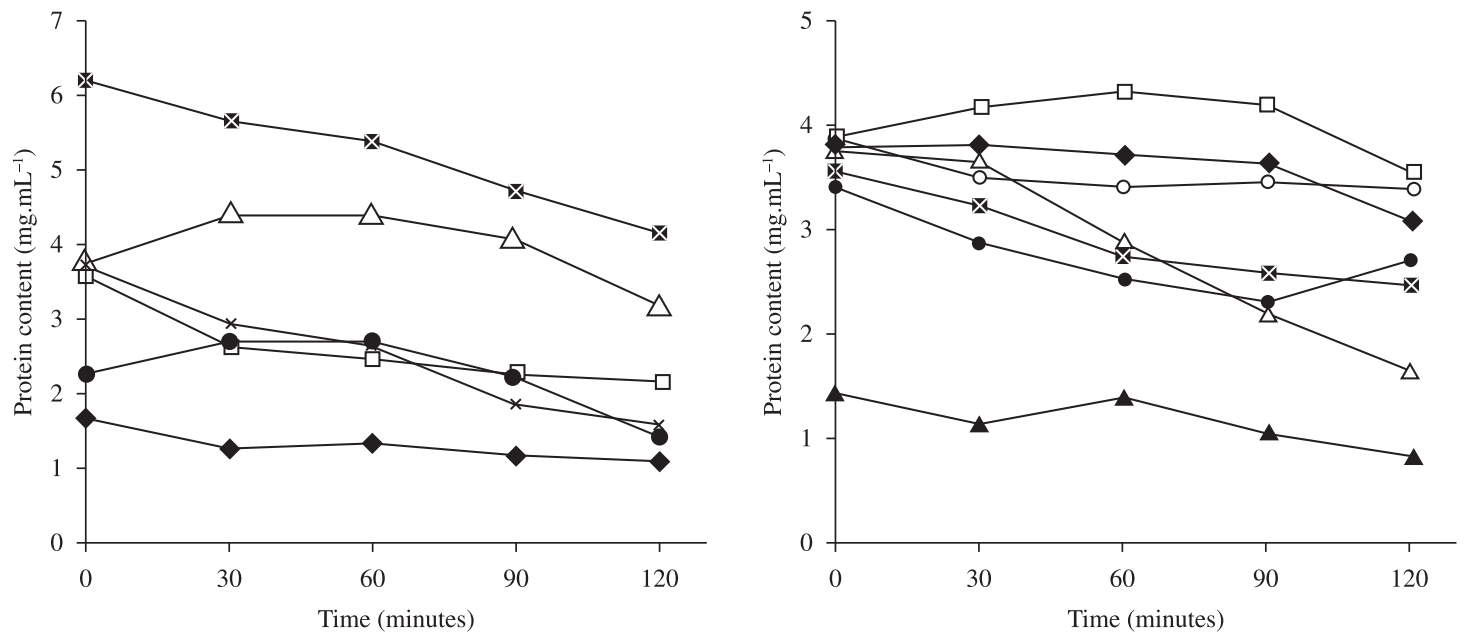

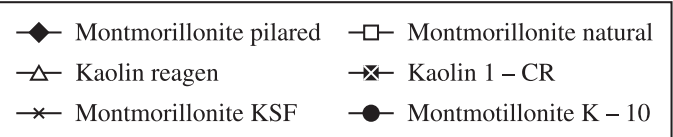

(a)

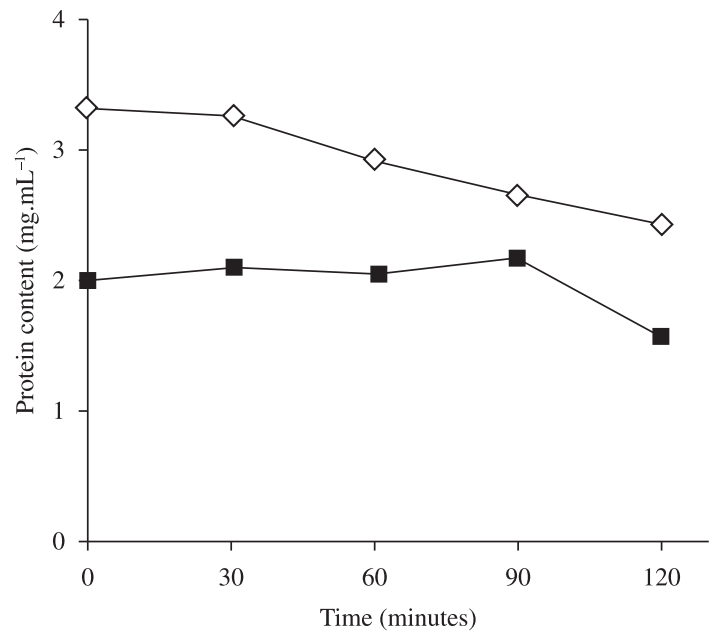

$\leadsto$ Amberlist $36 \rightarrow$ Amberlite XAD - 2

(c)

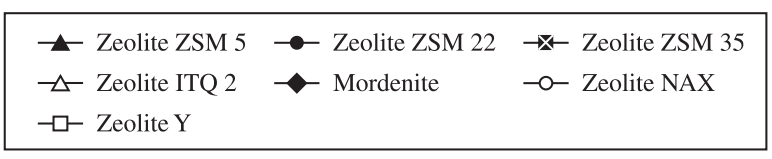

(b)

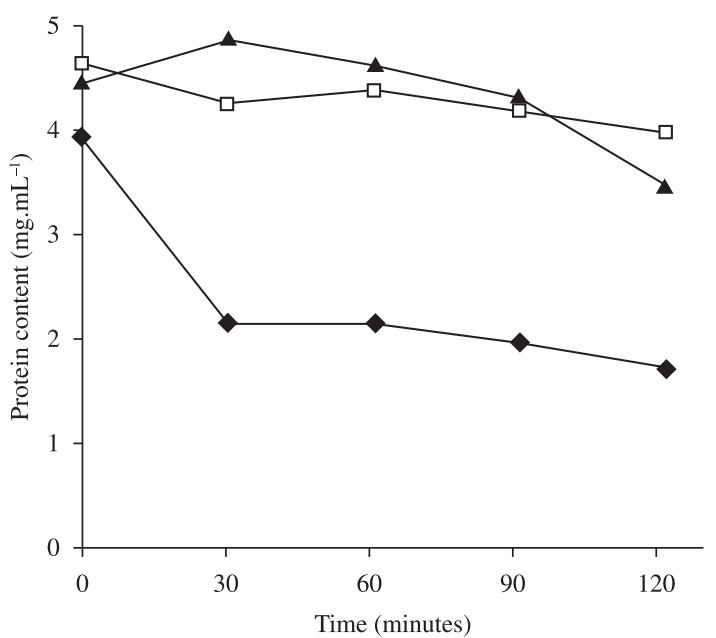

Alumina neutral $\rightarrow-$ Alumina acid

Alumina basic

(d)

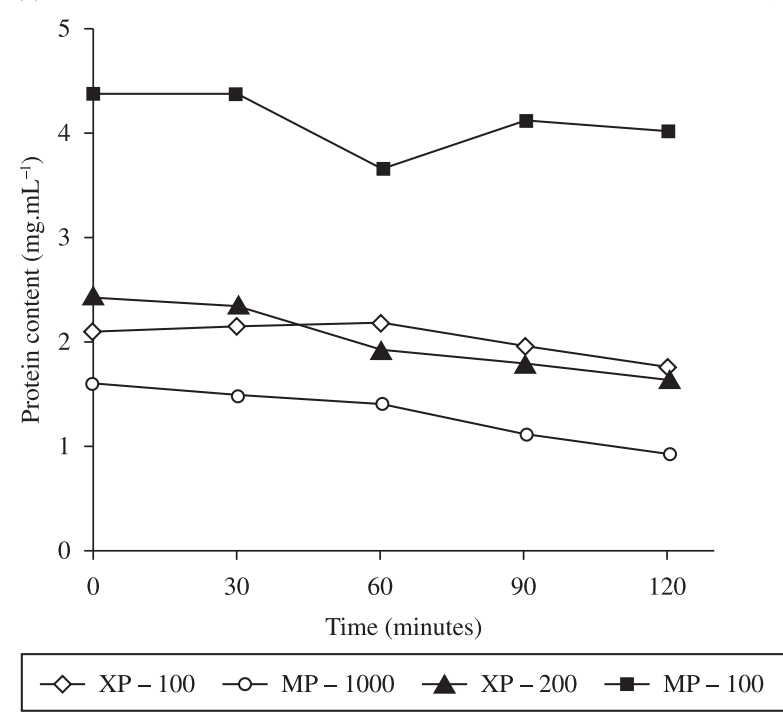

(e)

Figure 2. Kinetic of adsorption of commercial lipase in: a) clays; b) zeolites; c) resins; d) aluminas; and e) Accurel. 
Table 2. Protein adsorbed in the surface of each support, yield of immobilization, amount of lipase immobilized and esterification activity.

\begin{tabular}{lcccc}
\hline \multicolumn{1}{c}{ Sample } & \multicolumn{3}{c}{ (a) Clays } \\
& $\begin{array}{c}\text { Adsorbed protein } \\
\left(\mathrm{mg} . \mathrm{mL}^{-1}\right)\end{array}$ & $\begin{array}{c}\text { Yield of immobilization } \\
(\%)\end{array}$ & $\begin{array}{c}\text { Lipase immobilized } \\
(\mathrm{g})\end{array}$ & $\begin{array}{c}\text { Esterification activity } \\
\left(\mathrm{U}^{-1}\right)\end{array}$ \\
\hline Free enzyme & - & - & - & 739.69 \\
Clay KSF & 2.1402 & 76.32 & 1.5340 & 20.91 \\
Natural montmorillonite & 1.3622 & 52.01 & 1.0481 & 248.28 \\
Clay K-10 & 0.8393 & 46.63 & 0.9367 & 326.49 \\
Kaolin 1-CR & 2.0470 & 36.12 & 0.7270 & 72.29 \\
Pillared montmorillonite & 0.5747 & 29.98 & 0.6053 & 515.71 \\
Kaolin commercial & 0.5624 & 16.47 & 0.3320 & 175.41 \\
\hline
\end{tabular}

Kaolin commercial

(b) Zeolites

\begin{tabular}{lcccc}
\hline \multicolumn{1}{c}{ Sample } & $\begin{array}{c}\text { Adsorbed protein } \\
\left(\mathrm{mg} \cdot \mathrm{mL}^{-1}\right)\end{array}$ & $\begin{array}{c}\text { Yield of immobilization } \\
(\%)\end{array}$ & $\begin{array}{c}\text { Lipase immobilized } \\
(\mathrm{g})\end{array}$ & $\begin{array}{c}\text { Esterification activity } \\
\left(\mathrm{U}^{-1}\right)\end{array}$ \\
\hline Free enzyme & - & - & - & 739.69 \\
Zeolite Y & 0.3343 & 12.46 & 0.2504 & 75.68 \\
Zeolite NaX & 0.4879 & 16.35 & 0.3281 & 162.57 \\
Mordenite & 0.7063 & 18.12 & 0.3627 & 591.88 \\
Zeolite ZSM 22 & 0.7069 & 19.98 & 0.4007 & 263.86 \\
Zeolite ZSM 35 & 1.0857 & 26.54 & 0.5329 & 92.95 \\
Zeolite ZSM 5 & 0.5921 & 34.38 & 0.6903 & 148.72 \\
\hline
\end{tabular}

(c) Resins

\begin{tabular}{lcccc}
\hline \multicolumn{1}{c}{ Sample } & $\begin{array}{c}\text { Adsorbed protein } \\
\left(\mathrm{mg} \cdot \mathrm{mL}^{-1}\right)\end{array}$ & $\begin{array}{c}\text { Yield of immobilization } \\
(\%)\end{array}$ & $\begin{array}{c}\text { Lipase immobilized } \\
(\mathrm{g})\end{array}$ & $\begin{array}{c}\text { Esterification activity } \\
\left(\mathrm{U} \cdot \mathrm{g}^{-1}\right)\end{array}$ \\
\hline Free enzyme & - & - & - & 739.69 \\
Amberlyst 36 & 0.9031 & 39.25 & 0.7930 & 321.43 \\
Amberlite XAD-2 & 0.4659 & 24.52 & 0.4965 & 595.51 \\
\hline
\end{tabular}

(d) Aluminas

\begin{tabular}{lcccc}
\hline \multicolumn{1}{c}{ Sample } & $\begin{array}{c}\text { Adsorbed protein } \\
\left(\mathrm{mg} \cdot \mathrm{mL}^{-1}\right)\end{array}$ & $\begin{array}{c}\text { Yield of immobilization } \\
(\%)\end{array}$ & $\begin{array}{c}\text { Lipase immobilized } \\
(\mathrm{g})\end{array}$ & $\begin{array}{c}\text { Esterification activity } \\
\left(\mathrm{U}_{\mathrm{g}} \mathrm{g}^{-1}\right)\end{array}$ \\
\hline Free enzyme & - & - & - & 739.69 \\
Neutral alumina & 2.1858 & 68.27 & 1.3740 & 173.82 \\
Acid alumina & 0.6720 & 25.18 & 0.5072 & 0 \\
Basic alumina & 0.9879 & 22.65 & 0.4566 & 0 \\
\hline \multicolumn{1}{c}{ Sample } & Adsorbed protein & Yield of immobilization & Lipase immobilized & Esterification activity \\
& $\left(\mathrm{mg} \cdot \mathrm{mL}^{-1}\right)$ & $(\%)$ & - & 739.69 \\
\hline Free enzyme & - & - & 0.7372 & 158.32 \\
Accurel MP-1000 & 0.6825 & 36.76 & 0.6960 & 213.60 \\
Accurel XP-200 & 0.7918 & 34.62 & 0.4073 & 540.01 \\
Accurel XP-100 & 0.4285 & 20.32 & 0.2064 & 754.03 \\
Accurel MP-100 & 0.3813 & 10.29 & &
\end{tabular}

residual esterification activity of $86 \%$, using hexanoic acid and ethanol as substrates. Cabral et al. ${ }^{34}$ evaluated the esterification activity and operational stability of Candida rugosa lipase in polyuretan foams and obtained 85.4 and $93.2 \%$ for each parameter, respectively. Oliveira et al. ${ }^{35}$ carried out the kinetic study for esterification of oleic acid and ethanol using Rhizomucor miehei lipase immobilized in Accurel EP700, obtaining a conversion of $80.17 \%$. Zaidan et al. ${ }^{31}$ determined the esterification activity of Candida rugosa lipase immobilized in mica modified by acid treatment. Authors reported yield of immobilization of $40.6 \%$ and lipase activity of $292.2{\mathrm{U} . \mathrm{g}^{-1}}^{-1}$ of support. Rahman et al. ${ }^{21}$ evaluated the esterification activity of
Candida rugosa lipase immobilized in natural Kaolin. Yields of immobilization of $77 \%$ and esterification activity of $90 \%$ compared to the free enzyme were achieved.

Concerning the data presented in Table 2(a) one can notice that higher esterification activities were achieved for enzyme immobilized in pillared montmorillonite and K-10. This result may probably be related to the highest specific areas of these supports, leading to high acessibility of the substrates to the active site of the enzyme. Yesiloglu and Yesim ${ }^{20}$ affirm that several clays, as bentonites, have a high potential to be used as adsorbents, due to their low cost and high surface area. 


\subsubsection{Zeolites}

Figure $2 \mathrm{~b}$ presents the adsorption kinetics of pancreatic lipase in the different zeolites tested in this work, where one can note that the enzyme was immobilized in an efficient way in all evaluated materials.

Table 2(b) presents the amount of adsorbed protein, yield and amount of enzyme immobilized and esterification activity of lipase immobilized in zeolites. This table shows that the zeolites ZSM 35 and ZSM 5 can be considered the most appropriate supports for immobilization, with yields reaching $25 \%$ in relation to the amount of free enzyme used.

In a general way, one can conclude that several inorganic materials can be used as support for immobilization of lipases, among them the zeolites $^{36}$. This class of compounds is of particular interest due to the high specific area (200 to $800 \mathrm{~m}^{2} . \mathrm{g}^{-1}$ ); hydrophylic and hydrophobic behaviors, giving the possibility of presenting eletrostatic interactions leading to different forms of ionic exchange; and the characteristic of chemical and mechanical resistance. Additional advantages as easy of dispersion and recuperation and high capacity of adsorption in water can also be considered for the use of this class of compounds as support for immobilization of biomolecules. In this sense, the structural composition of zeolites offers a powerful tool for optimizing the properties of the biocatalyst. The main disadvantage is related to the low dimensions of pores. This characteristic can make difficult the process of migration of the enzyme to the inlet of zeolitic matrix, hinding the total efficiency of immobilization process.

In spite of the potential of using zeolites as support for lipases immobilization, just a few works were found in the literature that permits comparison with the results obtained here. Vidinha et al.${ }^{37}$ used the sol-gel encapsulation technique for immobilization of cutinase in zeolites $\mathrm{A}$ and $\mathrm{NaY}$, reaching yields of immobilization of 41 and $75 \%$, for each support, respectively. Yagiz et al. ${ }^{36}$ used hydrotalcite and zeolites 13-X, 5A, FM-8 and AW-300 for immobilization of a commercial lipase (Lipozyme-TL IM). Yields of immobilization of 95.8 and $56.1 \%$ were obtained for hydrotalcite and zeolites, respectively. Frontera et al. ${ }^{38}$ tested silicalite- 1 for immobilization of a commercial lipase from Rhizomucor miehei (Patalase), reaching a yield of immobilization of $59 \%$ and $228 \mathrm{mg}$ of lipase/g of support.

Calgaroto et al. ${ }^{39}$ used the MCM 22 zeolite with different $\mathrm{Si} / \mathrm{Al}$ ratios $(15,25$ and 50$)$ as support for immobilization of porcine pancreatic lipase, assessing the effect of its structure on the immobilization yield and enzyme activity. Results showed that the material composition influenced significantly the immobilization process. Higher yields of immobilization and enzymatic activities were achieved when MCM 22 with $\mathrm{Si} / \mathrm{Al}$ ratio of 25 was used as support. In general, results demonstrate the potential of MCM 22 as support for porcine pancreatic lipase immobilization.

Macario et al. ${ }^{40}$ immobilized Rhizomucor miehei lipase in zeolites ITQ-2, ITQ-6, Na-Silicalite-1, H-Silicalite-1 and MCM-41. The results of immobilization for each material were: $74 \%$ for Na-Silicalite-1, 66\% for H-Silicalite-1, 41\% for MCM-41, 27\% for ITQ-2 for $17 \%$ when ITQ-6 was used as support. Knezevic et al. ${ }^{41}$ immobilized Candida cylindracea lipase using zeolite $\mathrm{Y}$ as support, reaching a yield of $33 \%$ and $8.2 \mathrm{mg} . \mathrm{g}^{-1}$ of protein adsorbed.

The esterification activities of the pancreatic lipase immobilized in zeolites are also presented in Table 2(b), where it can be seen that higher activities were obtained when mordenite and zeolite ZSM 22

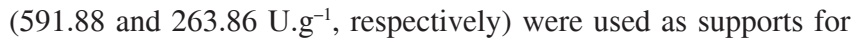
immobilization. From these results one can point out that the enzyme activities as well as the amount of enzyme immobilized are parameters directly influenced by the composition and porosity of the support.

Related to this specific result, one can cite the work by Abdullah et al. $^{42}$ that employed zeolites SBA-15 and amino- funcionalized SBA-15 for immobilization of Candida rugosa lipase, obtaining yields of 76 and $86.6 \%$, respectively. Zeng et al. ${ }^{43}$ used hydrotalcite for immobilization of lipase from Saccharomyces cerevisiae and obtained a percentual of retention of $95 \%$.

\subsubsection{Ionic exchange resins}

Figure $2 \mathrm{c}$ presents the kinetics of pancreatic lipase adsorption in the different resins tested in this work, where one can verify that the enzyme was immobilized in an efficient way in all evaluated materials. The ionic exchange resin with acid characteristics led to better results of immobilization, in spite of its lower specific area compared to other tested materials.

Table 2(c) presents the amount of adsorbed protein, the yield of immobilization and the esterification activity of the enzyme immobilized in each resin. Results from this table show that the acid ion exchange resin (Amberlyst 36) demonstrated better ability for immobilization of lipase compared to Amberlite XAD-2, which presents base-characteristics. This resin can reduce the interactions between the enzyme and support matrix. Nevertheless, the adsorption may be predominantly occurred on the external surface of the support due to the high molecular dimensions of the enzyme or also due to the hydrophobic interactions of the enzyme and the matrix, causing a conformational change in the secondary and tertiary structures of the protein molecule, reducing the interactions among the aromatic groups of the support and enzyme, leading to a lower yield of immobilization compared to the acid resin Amberlyst 36 .

Spagna et al. ${ }^{29}$ used different acrylic resins Amberlites XAD (XAD 2, 4, 16, 7 and 8) for immobilization of pectiniliase, obtaining different yields of immobilization $(38,30,18,20$ and $12 \%$, respectively) and different enzyme activities (11.5, 2.0, 36.0, 190.0 and $22.0 \mathrm{U} . \mathrm{g}^{-1}$, respectively). Bagi et al. ${ }^{44}$ tested several materials (polyacrylamide, poluethylene tereftalate, alumina and Celite) for immobilization of pancreatic lipase, reaching amounts of adsorbed protein of $145,36,31$ and $32 \mathrm{mg} \cdot \mathrm{g}^{-1}$ of support and catalytic activities of 21.9, 360.0, 86.0 and 75.0 U.g ${ }^{-1}$, respectively. Gandhi et al. ${ }^{45}$ employed ion exchange resins Indion 850 and 860, and Duolite A368 for immobilization of Mucor miehei lipase and reached residual activities of 30,10 and $17 \%$, respectively.

Both resins tested here presented good efficiency for immobilization of pancreatic lipase in terms of esterification activity, as also verified in Table 2(c). A low enhancement on enzyme activity was observed for Amberlite XAD-2, probably due to the basecharacteristics of this matrix, providing higher accessibility of the enzyme to the substrates during the catalytic process.

\subsubsection{Aluminas}

Activated aluminas are produced from aluminum hydroxide by hydroxilation, resulting in a material constituted mainly by aluminum oxide. The result of this process is a highly porous material with high specific area, reaching $200 \mathrm{~m}^{2} . \mathrm{g}^{-1}$, giving to this material a possibility of using in a large variety of applications in adsorption processes. Table 2(d) and Figure 2d present the results obtained in this step of the work. The analysis of these results permits us to notice a similar behavior during the adsorption process for all used materials. The comparison of materials showed higher amounts of adsorbed protein when neutral alumina was used as support for lipase immobilization.

Table 2(d) presents the results of amount of adsorbed protein, yield of immobilization and the amount of immobilized lipase in each support. Results show that neutral alumina can be considered the most promising support for immobilization, reaching yields of $68 \%$.

Padmini et al. ${ }^{46}$ immobilized Candida lipolytica lipase by adsorption in alumina, reaching a yield of immobilization of $69 \%$, a similar result to those obtained in this work. 


\subsubsection{Accurel XP-100, MP-100, XP-200 and MP-1000}

Table 2(e) presents the results in terms of adsorbed protein, yield and amount of lipase immobilized and esterification activity of porcine pancreatic lipase using different Accurel as support. Figure 2e shows the kinetic of adsorption of commercial lipase in Accurel. From this figure one can observe the similar behavior obtained for the different Accurel supports tested in this step of the work. Accurel XP200 and MP1000 presented higher amounts of adsorbed protein. From Table 2(e) it is possible to verify the good capacity of immobilization of lipase in these supports, reaching yields higher than $34 \%$. The Accurel MP100 presented the lowest immobilization yield probably due to the low specific area of this support.

Villeneuve et al. ${ }^{4}$ verified that polymeric resins, such as Accurel EP100 (actually Accurel MP1000), are examples of supports appropriated for enzymes immobilization. Kaewthong et al. ${ }^{47}$ immobilized PS Amano lipase in Accurel. The authors obtained yields of $37.16 \%$ for Accurel EP100 $(<200 \mu \mathrm{m})$ and $31.10 \%$ in Accurel EP100 (200-400 $\mu \mathrm{m})$. Results from the literature are comparable to that obtained in this work.

Menoncin et al. ${ }^{48}$ used Accurel EP100 and activated coal for immobilization of a crude enzymatic extract from Penicillium verrucosum. Percentages of retention of 368.1 and $382.5 \%$ and yields of immobilization of 11.7 and $30.4 \%$ were obtained for each tested support, respectively. Serralha et al. ${ }^{49}$ used the polymeric resin Accurel PA6 and zeolite Y for immobilization of cutinase, obtaining higher specific activities of $15.2 \mathrm{U} \cdot \mathrm{mg}^{-1}$ for resin and $25.1 \mathrm{U} \cdot \mathrm{mg}^{-1}$ for zeolite. Gonçalves et al. ${ }^{50}$ also tested the supports used in this step of our work for immobilization of cutinase. The authors obtained yields of immobilization of 69 and 30\%, respectively in zeolite and Accurel. The hydrolytic activity of the enzyme was 91.7 and $111{\mathrm{U} . \mathrm{g}^{-1}}$, respectively for each support. Yang et al. ${ }^{51}$ immobilized lipase from Candida sp. 99-125 in different macroporous polymeric resins (NKA9, AB8, H103, D4020 and NKA) by adsorption. Yields of immobilization of $16.84,62.06,84.13,65.80$ and $72.85 \%$ were obtained for each support, respectively. Enzyme activities of 10.5, $38.9,16.9,63.8$ and $26{\mathrm{U} . \mathrm{g}^{-1}}^{-1}$ were obtained for each support tested.

From Table 2(e) one can also verify the esterification activities of pancreatic lipase after immobilization in different Accurel. The lipase immobilized in Accurel MP-100 presented high esterification activity (754.03 $\mathrm{U.g}^{-1}$ ) compared to the use of other supports. This fact can be associated to the high chemical bond or eletrostatic atraction of the enzyme for this support, which make the active site of the enzyme accessible to the substrates, leading to high esterification activities, comparable to those from free lipase.

For better understanding of the results obtained in this work, Table 3 presents the compilation of all findings in terms of yield of immobilization and esterification activity of pancreatic lipase considering the most promising supports tested. Clay KSF led to the highest yield of immobilization (76.32\%) compared to the other tested matrix of immobilization. Esterification activities next to those obtained for free lipase were achieved in each group of supports tested

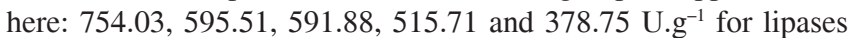
immobilized in Accurel MP-100, Amberlite XAD-2, mordenite and pillared montmorillonite, respectively.

The literature points out that from several supports used, clays and related materials present properties potentially interesting for application as supports agents for lipases immobilization. Hydrophobic and hydrophylic behavior; eletrostatic interactions and mechanical, chemical and microbial resistances are some of desirable characteristics present in this class of support. Another advantage of using clays as supports for enzyme immobilization is related to the presence of silanol groups which, after activation by different
Table 3. Compilation of the results for yield of immobilization and esterification activity of pancreatic lipase considering the most promising supports used in this work.

\begin{tabular}{lcc}
\hline \multicolumn{1}{c}{ Sample } & $\begin{array}{c}\text { Yield of } \\
\text { immobilization (\%) }\end{array}$ & $\begin{array}{c}\text { Esterification } \\
\text { activity }\left(\mathrm{U} . \mathrm{g}^{-1}\right)\end{array}$ \\
\hline Clay KSF & 76.32 & 20.91 \\
Neutral alumina & 68.27 & 173.82 \\
Natural montmorillonite & 52.01 & 248.28 \\
Clay K-10 & 46.63 & 326.51 \\
Amberlyst 36 & 39.25 & 321.43 \\
Pillared montmorillonite & 29.98 & 515.71 \\
Amberlite XAD-2 & 24.52 & 595.55 \\
Mordenite & 18.12 & 591.88 \\
\hline
\end{tabular}

functional groups, act as sites of linkage for bioactive species. Therefore, the clays have the possibility of being sinthetized, affording a series of reprodutible solid inorganic materials with physical and/ or chemical properties which can be changed in a systematic way to produce a more adequate support for a determined application as support for immobilization of macromolecules. The bentonite (montmorillonite) is a cheap matrix, presents low toxicity and chemical reactivity, permitting, in this way, the fixation of enzymes under its structure.

\section{Conclusions}

New experimental data on the performance of different supports for the immobilization of commercial porcine pancreatic lipase is reported in this work, showing a perspective of the technique to purpose low-costs supports for lipase immobilization. The partial characterization of the supports showed significant morphological differences among them. The characteristics of each support influenced the amount of adsorbed enzyme, the yields of immobilization and esterification activity of the enzyme. The clays $\mathrm{KSF}$, natural and pillared montmorillonites presented high potential for use as supports for lipase immobilization. Yields of immobilization of 76.32 and $52.01 \%$ were obtained for lipase immobilized in KSF and natural montmorillonite clay, respectively. High esterification activities (754.03, 595.51, 591.88 and $\left.515.71 \mathrm{U.g}^{-1}\right)$ were obtained for lipases immobilized in different class of supports tested here (Accurel MP-100, Amberlite XAD-2, mordenite and pillared montmorillonite respectively).

\section{References}

1. Abbas H, Hiol A, Deyris V and Comeau L. Isolation and characterization of an extracellular lipase from Mucor sp. strain isolated from palm fruit. Enzyme and Microbial Technology. 2002; 31:968-975. http://dx.doi. org/10.1016/S0141-0229(02)00190-4

2. Treichel H, Oliveira D, Mazutti M A, Di Luccio M and Oliveira VJ. A review on microbial lipases production. Food and Bioprocess Technology. 3:182-196 (2010). http://dx.doi.org/10.1007/s11947-009-0202-2

3. Sun SY and Xu Y. Solid-state fermentation for whole-cell synthetic lipase production from Rhizopus chinensis and identification of the functional enzyme. Process Biochemistry. 2008; 43:219-224. http://dx.doi.org/10.1016/j.procbio.2007.11.010

4. Villeneuve P, Muderhwa JM, Graille J and Hass MJ. Customizing lipases for biocatalysis: a survey of chemical, physical and molecular biological approaches. Journal of Molecular Catalysis B: Enzymatic. 2000; 9:113-148. http://dx.doi.org/10.1016/S1381-1177(99)00107-1 
5. Sebrão D, Silva VD, Nascimento MG and Moreira MA. Imobilização de lipases em filme de caseinato de sódio/Glicerol: Aplicação na síntese de ésteres. Química Nova. 2007; 30:1181-1187.

6. Dimitriu E, Secundo F, Patarin J and Fechete I. Preparation and properties of lipase immobilized on MCM-36 support. Journal of Molecular Catalysis B: Enzymatic. 2003; 22:119-133. http://dx.doi.org/10.1016/ S1381-1177(03)00015-8

7. Dalla-Vecchia R, Nascimento MG and Soldi V. Aplicações sintéticas de lipases imobilizadas em polímeros. Química Nova. 2004; 27:623-630. http://dx.doi.org/10.1590/S0100-40422004000400017

8. Bom EPS, Ferrara MA and Corvo ML. Enzimas em biotecnologia: Produção, Aplicações e Mercado. Rio de Janeiro: Interciencia; 2008. cap. 6.

9. Cardias HCT, Grininger CC, Trevisan HC, Guisan JM and Giordano RLC. Influence of activation on the multipoint immobilization of penicillin-G-acylase on macroporous sílica. Brazilian Journal of Chemical Engineering. 1999; 16:141-148. http://dx.doi.org/10.1590/ S0104-66321999000200005

10. Gomes FM, Paula AV, Silva GS and Castro HF. Determinação das propriedades catalíticas em meio aquoso e orgânico da lipase de Candida rugosa imobilizada em celulignina quimicamente modificada por carbonildilmidazol. Química Nova. 2006; 29:710-718. http://dx.doi. org/10.1590/S0100-40422006000400016

11. Oliveira PC, Alves GM and Castro HF. Síntese de butirato de butila empregando lipase microbiana imobilizada em copolímero de estirenodivinilbenzeno. Química Nova. 2000; 23:632-636. http://dx.doi. org/10.1590/S0100-40422000000500012

12. Hernádez-Jústiz O, Fernadez La Fuente R, Terreni M and Guisan J M. Use of aqueous two-phase systems for in situ extraction of water soluble antibiotics during their synthesis by enzymes immobilized on porous supports. Biotechnology and Bioengineering. 1998; 59:73-79. http://dx.doi.org/10.1002/(SICI)1097-0290(19980705)59:1\%3C73::A ID-BIT10\%3E3.0.CO;2-3

13. Fuentes IE, Viseras CA, Ubiali D, Terreni M and Alcantara AR. Different phyllosilicates as supports for lipase immobilization. Journal of Molecular Catalysis B: Enzymatic. 2001; 11:657-663. http://dx.doi.org/10.1016/ S1381-1177(00)00069-2

14. Yiu HHP, Wright PA and Botting NP. Enzyme immobilization using siliceous mesoporous molecular sieves. Microporous and Mesoporous Materials. 2001; 44:763-768. http://dx.doi.org/10.1016/S13871811(01)00258-X

15. Corma A, García H and Miralles J. High activity of layered zeolite ITQ-2 as catalyst for the hydroxyalkylation of 2-methoxynaphalene and naphthalene with paraformaldehyde. Comparation of its performance with that of conventional zeolites or mesoporous Al/MCM-41. Microporous and Mesoporous Materials. 2001; 43:161-169. http://dx.doi.org/10.1016/ S1387-1811(00)00359-0

16. Watanabe $Y$, Shimada $Y$, Sugihara A, Noda H, Fukuda H and Tominaga Y. Continuous production of biodiesel fuel from vegetable oil using immobilized Candida antarctica lipase. JAOCS. 2000; 77:355-360. http://dx.doi.org/10.1007/s11746-000-0058-9

17. Bradford MM. A rapid and sensitive method for the quantification of microgram of protein utilizing the principle of protein-drye binding. Analytical Biochemistry. 1976; 72:248-254. http://dx.doi. org/10.1016/0003-2697(76)90527-3

18. Rigo RT, Pergher SBC and Petkowicz DI. Um novo procedimento de síntese da zeólita A empregando argilas naturais. Química Nova. 2009; 32:21-25. http://dx.doi.org/10.1590/S0100-40422009000100004

19. Yesiloglu Y. Immobilized lipase-catalyzed ethanolysis of sunflower oil. JAOCS. 2004; 81:157-160. http://dx.doi.org/10.1007/s11746-004-0874-y

20. Yesiloglu Y. Utilization of bentonite as a support material for immobilization of Candida rugosa lipase. Process Biochemistry. 2005; 40:2155-2159. http://dx.doi.org/10.1016/j.procbio.2004.08.008

21. Rahman MBA, Tajudin SM, Hussein MZ, Salleh AB and Basri M. Application of natural kaolin as support for the immobilization of lipase from Candida rugosa as biocatalyst for effective esterification.
Applied Clay Science. 2005; 29:111-116. http://dx.doi.org/10.1016/j. clay.2004.12.001

22. Sanjay G and Sugunan S. Enhanced $\mathrm{pH}$ and thermal stabilities of invertase immobilized on montmorillonite K-10. Food Chemistry. 2006; 94:573-579. http://dx.doi.org/10.1016/j.foodchem.2004.12.043

23. Gopinath $\mathrm{S}$ and Sugunan S. Enzymes immobilized on montmorillonite K-10: Effect of adsorption and grafting on the surface properties and the enzyme activity. Applied Clay Science. 2007; 35:67-75. http://dx.doi org/10.1016/j.clay.2006.04.007

24. Meunier SM and Legge RL. Evaluation of diatomaceous earth as a support for sol-gel immobilized lipase for transesterification. Journal of Molecular Catalysis B: Enzymatic. 2010; 62:53-58. http://dx.doi. org/10.1016/j.molcatb.2009.09.002

25. Li Y, Zhou G, Li C, Qin D, Qiao W and Chu B. Adsorption and catalytic activity of porcine pancreatic lipase on Rod-like SBA-15 mesoporous material. Colloids and Surfaces A: Physicochemical and Engineering Aspects. 2009; 341:79-85. http://dx.doi.org/10.1016/j. colsurfa.2009.03.041

26. Li Y, Zhou G, Qiao W and Wang Y. Immobilization of porcine pancreas lipase on fiber-like SBA-15 mesoporous material. Materials Science and Engineering: B. 2009; 162:120-126. http://dx.doi.org/10.1016/j. mseb.2009.03.016

27. Ganapati D, Yadav S and Jadhav R. Synthesis of reusable lipases by immobilization on hexagonal mesoporous silica and encapsulation in calcium alginate: Transesterification in non-aqueous medium. Microporous and Mesoporous Materials. 2005; 86:211-222.

28. Zamora PP, Pereira CM, Tiburtius ERL, Moraes SG, Rosa MS, Minussi $\mathrm{RC}$ et al. Microbial laccases and their applications: A review. Applied Catalysis B: Environmental. 2003; 42:131-144.

29. Spagna G, Pifferi PG and Gilioli E. Immobilization of a pectinlyase from Aspergillus niger for application in food technology. Enzyme and Microbial Technology. 1995; 17:729-738. http://dx.doi.org/10.1016/01410229(94)01134-I

30. Chang S, Yen YH and Shied CJ. Optimum immobilization of Candida rugosa lipase on Celite by RSM. Applied Clay Science. 2007; 37:67-73. http://dx.doi.org/10.1016/j.clay.2006.12.001

31. Zaidan UH, Rahman MBA, Barsi M, Othman SS and Salleh AB. Silylation of mica for lipase immobilization as biocatalysts in esterification. Applied Clay Science. 2010; 47:276-282.

32. Secundo F, Miehé-Brendlé J, Chelaru C, Ferrandi EE and Dumitriu E. Effective immobilization of Candida antarctica lipase B in organic-modified clays: Application for the epoxidation of terpenes. Microporous and Mesoporous Materials. 2008; 109:350-361. http://dx.doi.org/10.1016/j.clay.2009.11.004

33. Dave R and Madamwar D. Esterification in organic solvents by lipase immobilized in polymer of PVA-alginate-boric acid. Process Biochemistry. 2006; 41:951-955. http://dx.doi.org/10.1016/j.procbio.2005.10.019

34. Cabral PP, Fonseca MMR and Diasc SF. Esterification activity and operational stability of Candida rugosa lipase immobilized in polyurethane foams in the production of ethyl butyrate. Biochemical Engineering Journal. 2010; 48:246-252. http://dx.doi.org/10.1016/j. bej.2009.10.021

35. Oliveira AC, Rosa MF, Barros MRA and Cabral JMS. Enzymatic esterification of ethanol and oleic acid - a kinetic. Journal of Molecular Catalysis B: Enzymatic. 2001; 11:999-1005. http://dx.doi.org/10.1016/ S1381-1177(00)00039-4

36. Yagiz F, Kazan D and Akin NA. Biodiesel production from waste oils by using lipase immobilized on hydrotalcite and zeolites. Chemical Engineering Journal. 2007; 134:262-267. http://dx.doi.org/10.1016/j. cej.2007.03.041

37. Vidinha P, Augusto V, Almeida M, Fonseca I, Fidalgo A, Ilharco L et al. Sol-gel encapsulation: Na efficient and versatile immobilization technique for cutinase in non-aqueous media. Journal Biotechnology. 2006; 121:23-33. PMid:16095741. http://dx.doi.org/10.1016/j. jbiotec. 2005.06.018 
38. Frontera D, Macario A, Katovic A, Crea F and Giordano G. Direct synthesis of zeolites self-bonded pellets for biocatalyst immobilization. Studies in Surface Science and Catalysis. 2005; 158:383-390. http://dx.doi.org/10.1016/S0167-2991(05)80363-5

39. Calgaroto C, Scherer RP, Calgaroto S, Oliveira JV, Oliveira D and Pergher SBC. Immobilization of porcine pancreatic lipase in zeolites MCM 22 with different Si/Al ratios. Applied Catalysis A: General. 2011; 394: 101-104. http://dx.doi.org/10.1016/j.apcata.2010.12.032

40. Macario A, Katovic A, Giordano G, Forni L, Carloni F, Filippini A et al. Preparation of mesoporous materials as a support for the immobilization of lipase. Studies in Surface Science and Catalysis. 2005; 155:1561-1568. http://dx.doi.org/10.1016/S0167-2991(05)80166-1

41. Knezevic Z, Mojovic L and Adnadjevic B. Palm oil hydrolysis by lipase from Candida cylindracea immobilized on zeolite type Y. Enzyme and Microbial Technology. 1998; 22:275-280. http://dx.doi.org/10.1016/ S0141-0229(97)00187-7

42. Abdullah A Z, Sulaiman N S and Kamaruddin AH. Biocatalytic esterification of citronellol with lauric acid by immobilized lipase. Biochemical Engineering Journal. 2009; 44:263-270. http://dx.doi. org/10.1016/j.bej.2009.01.007

43. Zeng HY, Liao K, Deng X, Jiang H and Zhang F. Characterization of the lipase immobilized on $\mathrm{Mg}$-Al hydrotalcite for biodiesel. Process Biochemistry. 2009; 44:791-798. http://dx.doi.org/10.1016/j. procbio.2009.04.005

44. Bagi K, Simon L M and Szajáni B. Immobilization ond characterization of porcine pancreas lipase. Enzyme and Microbial Technology. 1997; 20:531-535. http://dx.doi.org/10.1016/S0141-0229(96)00190-1
45. Gandhi NN, Vijayalakshmi V, Sawant SB and Joshi JB. Immobilization of Mucor miehei lipase on ion exchange resins. Chemical Engineering Journal. 1996; 61:149-156.

46. Padmini P, Rakshit SK and Baradarajan B. Studies on immobilization of lipase on alumina for hydrolysis of rice bran oil. Bioprocess and Biosystems Engineering. 1993; 9:43-46.

47. Kaewthong W, Srisansaneeyakul S, Prasertsan P and H-Kittikun A. Continuous production of monoacylglycerols by glycerolysis of palm olein with immobilized lipase. Process Biochemistry. 2005; 40:1525-1530. http://dx.doi.org/10.1016/j.procbio.2003.12.002

48. Menoncin S, Domingues NM, Freire DMG, Oliveira JV, Di Luccio M, Treichel H et al. Imobilização de lipases produzidas por fermentação em estado sólido utilizando Penicillium verrucosum em suportes hidrofóbicos. Ciência Tecnologia de Alimentos. 2009; 29 440-443. http://dx.doi.org/10.1590/S0101-20612009000200033

49. Serralha FN, Lopes JM, Lemos F, Ribeiro R, Prazeres DMF, Aires-Barros MR et al. Application of factorial design to the study of an alcoholysis transformation promoted by cutinase immobilized on $\mathrm{NaY}$ zeolite and Accurel PA6. Journal of Molecular Catalysis B: Enzymatic. 2004; 27:19-27. http://dx.doi.org/10.1016/j.molcatb.2003.09.005

50. Gonçalves APV, Lopes JM, Lemos F, Ribeiro R, Prazeres DMF, Cabral JMS et al. Effect of the immobilization support on the hydrolytic activity of a cutinase from Fusarium solani pisi. Enzyme and Microbial Technology. 1997; 20:93-101. http://dx.doi.org/10.1016/S0141-0229(96)00089-0

51. Yang G, Tian-Wei T, Kai-LI N and Fang W. Immobilization of lipase on macroporous resin and its application in synthesis of biodiesel in low aqueous media. Chinese Journal of Biotechnology. 2006; 22 114-118. http://dx.doi.org/10.1016/S1872-2075(06)60008-3 